\title{
Methanococcus Thermolithotrophicus, a Novel Thermophilic Lithotrophic Methanogen
}

\author{
Harald Huber ${ }^{1}$, Michael Thomm ${ }^{1}$, Helmut König ${ }^{1}$, Gesa Thies ${ }^{2}$, and Karl O. Stetter ${ }^{1}$ \\ 1 Lehrstuhl für Mikrobiologie, Universität Regensburg, D-8400 Regensburg, Federal Republic of Germany \\ 2 Lehrstuhl für Zoologie, Universität Regensburg, D-8400 Regensburg, Federal Republic of Germany
}

\begin{abstract}
An autotrophic thermophilic motile coccoid methanogen was isolated from geothermally heated sea sediments close to Naples, Italy. Growth occurs on $\mathrm{H}_{2} / \mathrm{CO}_{2}$ and on formate between 30 and $70^{\circ} \mathrm{C}$ with an optimum at $65^{\circ} \mathrm{C}$. The optimal doubling time is only $55 \mathrm{~min}$. The $\mathrm{NaCl}$ concentration ranges from $1.3 \%$ to $8.3 \%$ with an optimum around $4 \%$. By its $\mathrm{G}+\mathrm{C}$-content of $31.3 \mathrm{~mol} \%$, its subunit envelope, and by DNA-RNA hybridization the new isolate is clearly defined to be a member of the genus Methanococcus. We name it Methanococcus thermolithotrophicus.
\end{abstract}

Key words: Methanogens - Archaebacteria - Autotrophic - Thermophilic

All thermophilic methanogens known so far are members of two orders, the Methanobacteriales and the Methanomicrobiales. The latter contains only one thermophilic strain, Methanosarcina TM-1 (Zinder and Mah 1979), which has been isolated from a sewage digestor and grows at a maximal temperature of $55^{\circ} \mathrm{C}$. The Methanobacteriales contain the thermophilic Methanobacterium thermoautotrophicum, which occurs in thermal springs and sewage digestors (Zeikus and Wolfe 1972; Zeikus et al. 1980), and grows between $37^{\circ} \mathrm{C}$ (Stetter unpublished) and $75^{\circ} \mathrm{C}$ (Zeikus and Wolfe 1973; Zeikus et al. 1980), and the extreme thermophilic species Methanothermus fervidus (Stetter et al. 1981), which was recently isolated from a hot spring in Iceland, and grows between 65 and $97^{\circ} \mathrm{C}$. In the order Methanococcales, 2 species, which can be cultivated only in the mesophilic temperature range, are known (Balch et al. 1979).

Here we report on the isolation and characterization of a new species of Methanococcus which grows at temperatures up to $70^{\circ} \mathrm{C}$.

\section{Materials and Methods}

\section{Strains}

Methanococcus voltae, DSM 1937, was obtained from the Deutsche Sammlung von Mikroorganismen, Göttingen.

\section{Culture Conditions}

The organisms were cultivated by using the technique described by Balch and Wolfe (1976). Methanococcus voltae was

Abbreviations. G + C: Guanine + Cytosine; SDS: Sodium dodecylsulfate (Sodium lauryl sulfate)

Offprint requests to: $\mathrm{K}$. O. Stetter grown in medium 3 of Balch et al. (1979), slightly modified (Wildgruber et al. 1982). For autotrophic growth of the new isolate, medium 3 of Balch et al. (1979), not containing sodium acetate, yeast extract, trypticase, and trace vitamines, pH 6.9 (adjusted with $\mathrm{H}_{2} \mathrm{SO}_{4}$ ), was used ("MGG medium"). Twenty milliliter cultures were grown in stoppered pressurized $100 \mathrm{ml}$ serum bottles (Bormioli, Italy) made of "type III"-glass by incubation in shakers (New Brunswick) at $140 \mathrm{rpm}$, employing a glycerol bath.

Enrichment and isolation medium ("supplemented sea water"): $750 \mathrm{ml}$ sea water was supplemented with the following ingredients: $\mathrm{Na}_{2} \mathrm{CO}_{3} 1 \mathrm{~g} ; \mathrm{NH}_{4} \mathrm{HCO}_{3} 2 \mathrm{~g}$; sodium formate $1 \mathrm{~g}$; sodium acetate $5 \mathrm{~g}$; yeast extract (Difco) $1 \mathrm{~g}$; tryptic digest of casein (Merck) $2 \mathrm{~g}$; trace vitamines (Balch et al. 1979) $10 \mathrm{ml}$; trace minerals (Balch et al. 1979) $10 \mathrm{ml} ; 2$ mercaptoethanesulfonic acid $0.1 \mathrm{mg}$; resazurin $1 \mathrm{mg}$; L-cysteine hydrochloride $\cdot \mathrm{H}_{2} \mathrm{O} 0.5 \mathrm{~g} ; \mathrm{Na}_{2} \mathrm{~S} \cdot 9 \mathrm{H}_{2} \mathrm{O} 0.5 \mathrm{~g}$. Then, the medium was completed to 11 with $\mathrm{H}_{2} \mathrm{O}$ dest. and the $\mathrm{pH}$ was adjusted to 7.5 (acetic acid). The media were sterilized for $20 \mathrm{~min}$ at $120^{\circ} \mathrm{C}$.

\section{Light Microscopy}

The cells were observed and photographed with a Leitz Ortholux II microscope, equipped with a vario-orthomat camera system (Leitz). Fluorescence was observed in a Zeiss Standard fluorescence microscope with an excitation filter H436 and a selection filter LP470.

\section{Electron Microscopy}

For platinum shadowing, the cells were fixed on collodium coated grids and shadowed with platinum-iridium under an angle of $7^{\circ}$. To prepare thin sections, cells were centrifuged and then fixed in MGG-medium with $20 \mathrm{~g}$ glutaraldehyde/ 1 for $2 \mathrm{~h}$ and postfixed with $10 \mathrm{~g} \mathrm{OsO}_{4} / 1$ for $1 \mathrm{~h}$. Durcupan (Fluka) epoxy resin was used for embedding and thin sections were contrasted with lead citrate $(5 \mathrm{~min})$, uranylacetate ( $5 \mathrm{~min}$ ) and again with lead citrate $(3 \mathrm{~min})$.

Electron micrographs were taken with a JEOL JEM $100 \mathrm{C}$ electron microscope at $80 \mathrm{kV}$ and with a $40 \mu \mathrm{m}$ objective aperture.

\section{Isolation of DNA}

The DNA's of Methanococcus voltae and the new isolate were prepared as described elsewhere (Wildgruber et al. 1982). 


\section{Analysis of the Cell Wall}

The existence of a cell wall sacculus was checked for as described (Stetter et al. 1981).

Muramic acid and glycoprotein were analyzed as described (König and Stetter, in preparation).

\section{Methane Detection}

Methane was determined with a Hewlett Packard gas chromatograph, model $5880 \mathrm{~A}$, using a 6 foot glass column filled with carbosieve $\mathrm{S}$ (Supelco) at $70^{\circ} \mathrm{C}$ isothermal.

\section{Temperature Measurement}

The temperature of the sea sediments was measured with an electronic thermometer (Metratherm 1200 d, BBC Metrawatt, Germany) equipped with a T 126 electrode.

\section{Results}

\section{Collection of the Sample}

The sample SN 1 was taken from the sandy geothermally heated sea floor of the beach at Stufe di Nerone close to Naples (Italy), about $3 \mathrm{~m}$ away from the shore in about $0.5 \mathrm{~m}$ depth. The original temperature of the sediment was $50^{\circ} \mathrm{C}$, the $\mathrm{pH} 6.5$ and the conductivity $7.5 \mathrm{mS}$, which is that of normal sea water. The sample was immediately filled into a sterile $100 \mathrm{ml}$ storage bottle, which was sealed with a rubber stopper after the addition of $0.1 \mathrm{ml}$ of resazurin $(0.1 \% \mathrm{w} / \mathrm{v}$ in water). The redox potential was then lowered as described (Wildgruber et al. 1982). The sample was carried to the laboratory at room temperature (around $20^{\circ} \mathrm{C}$ ).

\section{Enrichment and Isolation}

In a freter type anaerobic chamber (Aranki and Freter 1972), a $100 \mathrm{ml}$ serum bottle containing $20 \mathrm{ml}$ "sea water supplemented" and $50 \mu \mathrm{g}$ vancomycin $/ \mathrm{ml}$ and $30 \mu \mathrm{g}$ penicillin $/ \mathrm{ml}$ was inoculated with $1 \mathrm{ml}$ of sample SN 1 . After sealing with a stopper, the bottle was pressurized $\left(300 \mathrm{kPa} \mathrm{H}: \mathrm{CO}_{2}=\right.$ 80:20; Balch and Wolfe 1976) and then incubated in a shaker (New Brunswick) at $50^{\circ} \mathrm{C}$. After 4 days, the medium became turbid and methane could be detected in the gas phase. In the fluorescence microscope, masses of strongly green fluorescing cocci were visible.

One milliliter culture was transferred into the same medium, and incubated at $70^{\circ} \mathrm{C}$. Next day the new organism, called SN 1, was grown without visible infection. This enrichment culture was streaked onto agar plates ( $2 \%$ agar) prepared with "supplemented sea water". After 1 week, round convex smooth yellow colonies, about $0.5-1 \mathrm{~mm}$ in diameter became visible.

\section{Culture and Storage}

Cultures were transferred each day into fresh MGG-medium ( $2 \%$ inoculation). For a long time preservation, the strain SN 1 was grown for $6 \mathrm{~h}$ and then, after renewing the gas atmosphere, it was stored at $4^{\circ} \mathrm{C}$, from where it can serve at least 6 months as inoculum.

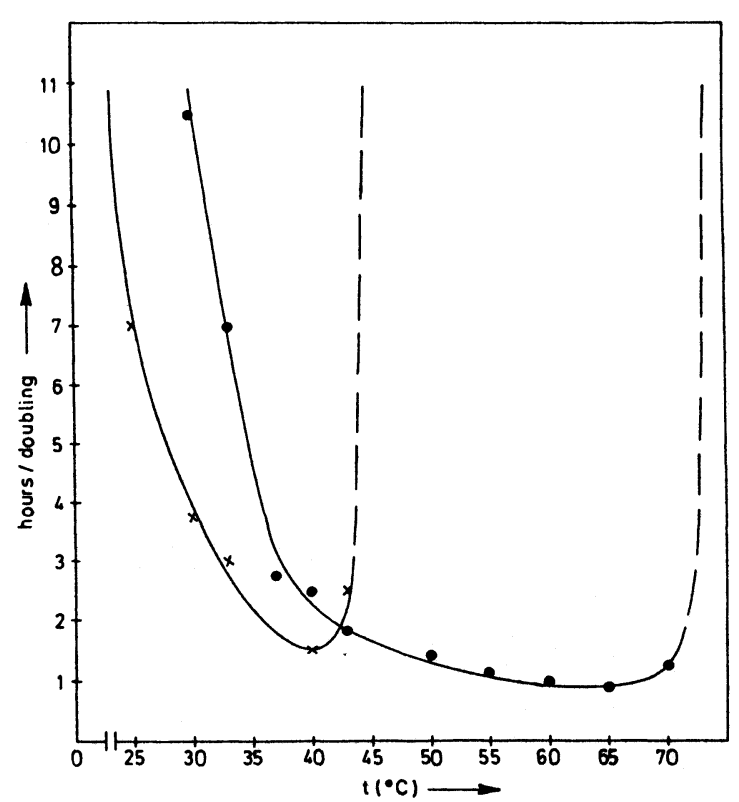

Fig. 1. Optimal growth temperature. $\times-\times$ Methanococcus voltae; Methanococcus thermolithotrophicus. Growth was determined several times during the exponential phase by O.D.578-measurement. The hours/doubling were calculated from the slopes of the growth curves (not shown)

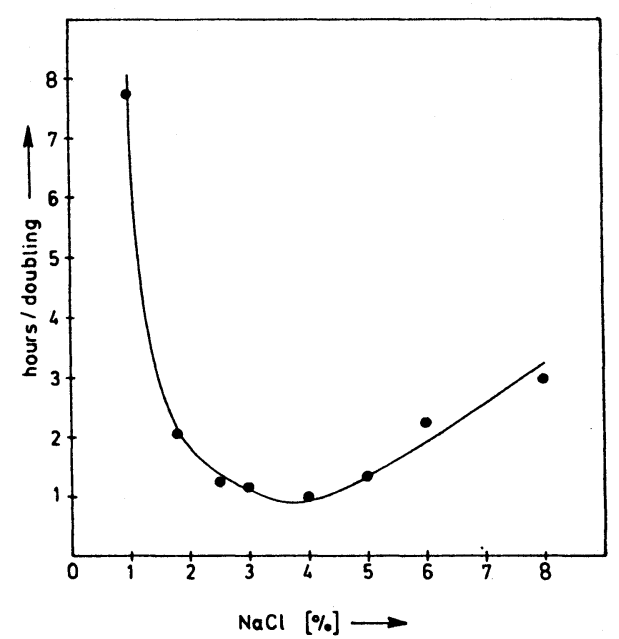

Fig. 2. Influence of $\mathrm{NaCl}$-concentration on growth of Methanococcus thermolithotrophicus. The $\mathrm{NaCl}$ was added to a MGG-medium, not supplemented with $\mathrm{NaCl}$. This basal medium already contains $0.33 \%$ $\mathrm{NaCl}$, which is not considered in the diagram

\section{Optimal Growth Temperatures}

The isolate $\mathrm{SN} 1$ shows a broad temperature range of growth between $30^{\circ} \mathrm{C}$ and $70^{\circ} \mathrm{C}$ (Fig. 1). At $75^{\circ} \mathrm{C}$ (data not shown) the O.D. 578 of the culture doubles within $5 \mathrm{~h}$, followed by a period of cell lysis within the next $6 \mathrm{~h}$. The shortest doubling time (Fig. 1) is only $55 \mathrm{~min}$ at $65^{\circ} \mathrm{C}$. For comparison, Methanococcus voltae shows (Fig. 1) a temperature optimum around $40^{\circ} \mathrm{C}$, under the same conditions.

\section{Substrates and Organic Components of the Medium}

$\mathrm{H}_{2}$ and formate serve as substrates for methane formation No organic components are required nor do they stimulate growth significantly (data not shown). 

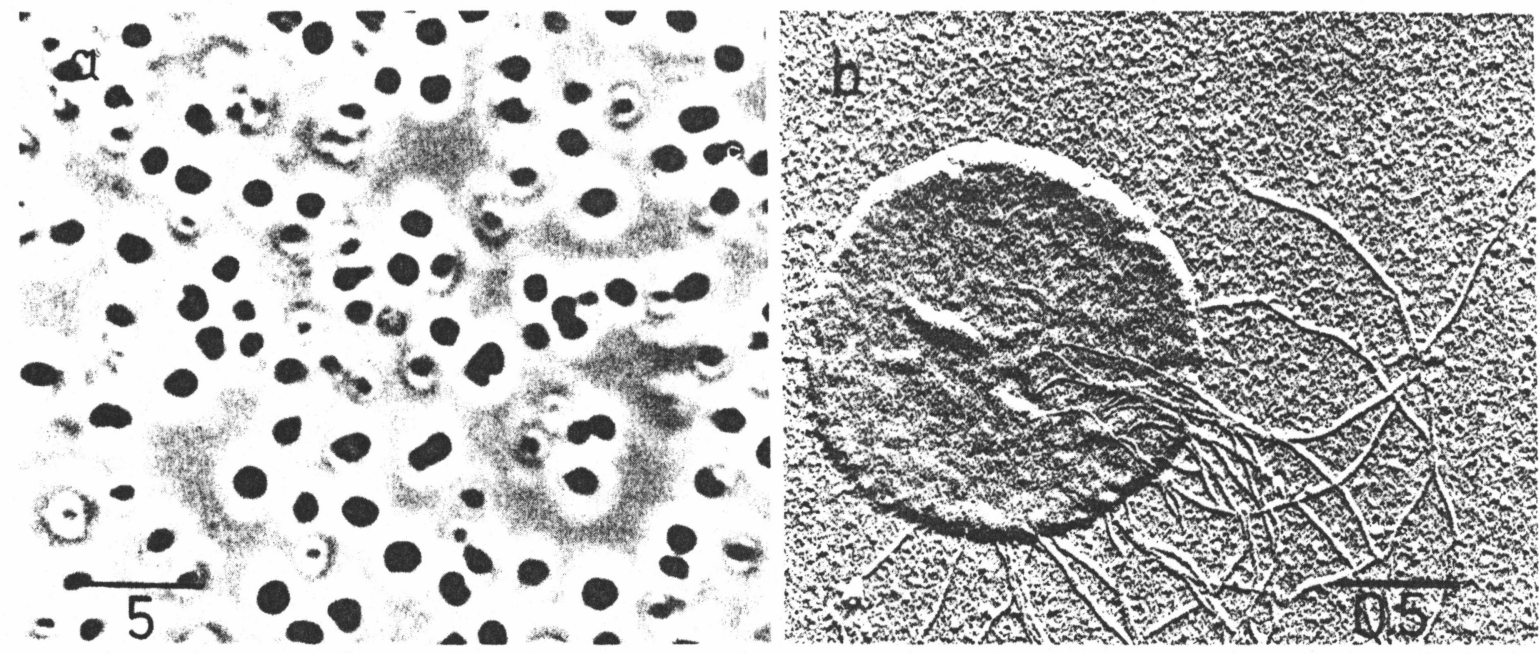

C

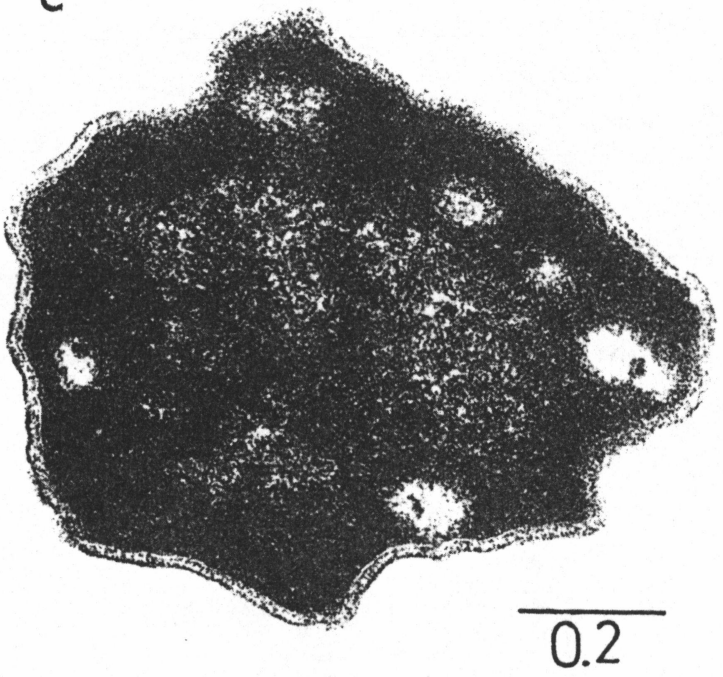

d

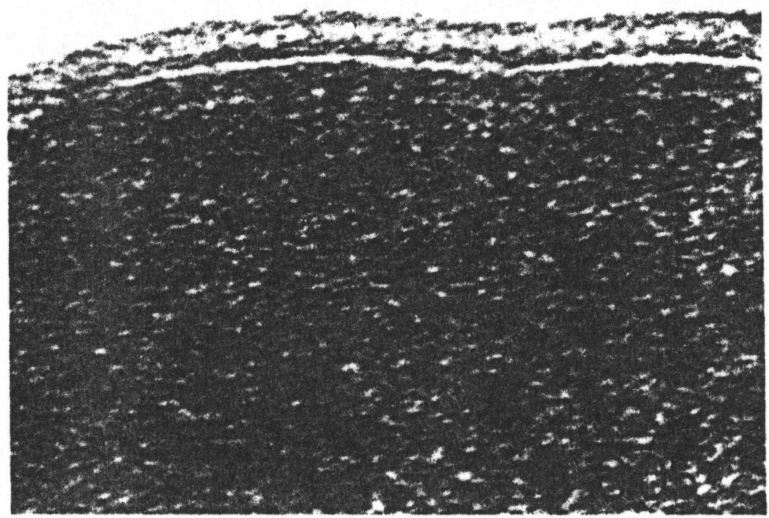

Fig. 3a-d. Light and electron micrographs of Methanococcus thermolithotrophicus. a Phase contrast; b platinum shadowed; $\mathbf{c}, \mathbf{d}$ thin sections. Statements of size in $\mu$ m

\section{Optimal Salt Concentration}

The isolate $\mathrm{SN} 1$ grows in the presence of $1.3-8.3 \% \mathrm{NaCl}$ (Fig. 2). The optimal concentration is around $4 \% \mathrm{NaCl}$.

\section{Optimal pH}

The new organism grows in a $\mathrm{pH}$ range from 6 to 8 with an optimum around 7 (data not shown).

\section{Morphology}

In the light microscope, regular to irregular highly motile cocci about $1.5 \mu \mathrm{m}$ in diameter, occurring singly and in pairs, can be seen (Fig. 3a). The cells are Gram-negative. In the presence of $2 \%$ SDS $(\mathrm{w} / \mathrm{v})$ the cells are immediately lysed. As seen in the electron microscope, a tuft of flagella is present, which is inserted in a distinct area on the cell surface (Fig. 3b). Each of the about 20 flagella of a cell is up to $3 \mu \mathrm{m}$ long and $20 \mathrm{~nm}$ thick. In thin sections a cell envelope can be seen (Fig. 3c), which consists of subunits, most likely of protein (Fig. 3d), similar to other Methanococci (Jones et al. 1977). No muramic acid and no glycoproteins could be detected in preparations of the cell envelope.

\section{DNA Base Composition}

The DNA contains $31.3 \mathrm{~mol} \% \mathrm{G}+\mathrm{C}$ as determined by the melting point in $1 \times \mathrm{SSC}$ (Marmur and Doty 1962) using I)NA of Methanococcus voltae as a reference $(30.7 \mathrm{~mol} \%$ $(\mathrm{i}+\mathrm{C})$.

A second analysis of the DNA base composition performed by HPLC chromatography of a nuclease P1 hydrolysate (Zillig et al. 1980) yielded at $G+C$-content of $31.6 \mathrm{~mol} \%$ for the isolate SN 1 .

\section{Discussion}

The isolate SN 1 is the first thermophilic Methanococcus. Its growth temperature optimum at $65^{\circ} \mathrm{C}$ is similar to that of Methanobacterium thermoautotrophicum (Zeikus et al. 1980). In contrast to the other coccoid methanogens described (Balch et al. 1979), yeast extract does not stimulate growth. With a doubling time of only $55 \mathrm{~min}$, the new isolate is the fastest growing archaebacterium known to date, even faster than Methanohacterium thermoautotrophicum, strain Marburg, which has an optimal doubling time of $1.6 \mathrm{~h}$ (Brandis et al. 1981). This rapid growth is similar to that of 
fast growing cubacterial anacrobians, e.g. Lactohacilli (K. O. Stetter, unpublished). Due to its vigorous growth and its autotrophy, the new isolate may be well suited for biochemical studies.

The new organism SN 1 is clearly determined to be a Methanococcus (Balch et al. 1979) by its coccoid shape, its substrate spectrum, its subunit cell envelope, and its DNA with a $\mathrm{G}+\mathrm{C}$-content of $31.3 \mathrm{~mol} \%$. In DNA-RNA hybridization experiments (Tu et al. 1982), very stable hybrids (fractional stability: 0.94) between the DNA of the isolate SN 1 and the labelled RNA of Methanococcus voltae were obtained, indicating a relatively close relationship with this species and confirming the affiliation to the Methanococcales.

Judging its place of isolation, its thermophily, its lithotrophic growth and its salt optimum, the isolate $\mathrm{SN} 1$ seems to be distributed in volcanic areas on the sea floor. It is named Methanococcus thermolithotrophicus.

Description and Classification of the Methanococ'us thermolithotrophicus

Order Methanococcales (Balch and Wolfe 1979)

Family Methanococcaceae (Balch and Wolfe 1979)

Genus Methanococcus (Barker 1936)

Methanococcus thermolithotrophicus; Huber, Thomm, and Stetter (sp. nov.)

ther.mo.li.tho.tro'phi.cus. Gr. fem. n. therme heat; Gr. masc. n. lithos stone; Gr. masc. n. trophos one who feeds; M. L. masc. adj. thermolithotrophicus thermophilic and lithotrophic.

Regular to irregular cocci, about $1.5 \mu \mathrm{m}$ in diameter, occurring singly or in pairs. On agar, round, convex, smooth, yellowish colonies, around $1 \mathrm{~mm}$ in diameter are formed. About 20 flagella are inserted at a distinct area on the cell surface. The cells are Gram-negative, and are lysed by $2 \%$ SDS; the cell envelope consists of subunits. Optimal growth is at $65^{\circ} \mathrm{C}$ with a doubling time of $55 \mathrm{~min}$. Growth takes place between 30 and $70^{\circ} \mathrm{C}$. The optimal $\mathrm{pH}$ is $6.5-7.5$. Culture is possible in the presence of $1.3-8.3 \% \mathrm{NaCl}$ with an optimal growth at $4 \%$. Methane is only formed from $\mathrm{H}_{2} / \mathrm{CO}_{2}$ and from formate. Organic material does not stimulate growth. The DNA base composition is $31.3 \mathrm{~mol} \% \mathrm{G}+\mathrm{C}$. In DNARNA hybridization, the DNA of the isolate forms hybrids with RNA of Methanococcus voltae with a fractional stability of 0.94 .

The type strain is DSM 2095 Göttingen, FRG.

Acknowledgements. The excellent technical assistance of Petra Frischeisen and Elisabeth Kleemeier is acknowledged. Thanks are due to Dr. Jurek Madon for HPLC analysis. Furthermore, we greatly appreciate the support in electron microscopy by Dr. Kurt Ober and by Davorin Janécovic.
This work was supported by a grant of the Deutsche Forschungsgemeinschaft to K. O. Stetter.

\section{References}

Aranki A, Freter R (1972) Use of anaerobic glove boxes for cultivation of strictly anaerobic bacteria. Am J Clin Nutr 25:1329-1334

Balch WE, Fox GE, Magrum LJ, Woese CR, Wolfe RS (1979) Methanogens: Reevaluation of a unique biological group. Microbiol Rev 43:260-296

Balch WE, Wolfe RS (1976) New approach to the cultivation of methanogenic bacteria: 2-mercaptoethansulfonic acid (HS-CoM)dependent growth of Methanohacterium ruminantium in a pressurized atmosphere. Appl Environ Microbiol 32: 781-791

Barker HA (1936) Studies on methane producing bacteria. Arch Mikrobiol 7:420-438

Brandis A, Thauer RK, Stetter KO (1981) Relatedness of strains $\Lambda \mathrm{H}$ and Marburg of Methanobacterium thermoautotrophicum. Zbl Bakt Hyg, I Abt Orig C 2:311-317

Jones JB, Bowers B, Stadtman TC (1977) Methanococcus vannielii: Ultrastructure and sensitivity to detergents and antibiotics. J Bacteriol 130:1357-1363

Marmur J, Doty P (1962) Determination of the base composition of deoxyribonucleic acid from its thermal denaturation temperature. $\mathbf{J}$ Mol Biol 5:109-118

Stetter KO, Thomm M, Winter J, Wildgruber G, Huber H, Zillig W, Janécovic D, König H, Palm P, Wunderl S (1981) Methanothermus fervidus, sp. nov., a novel extremely thermophilic methanogen isolated from an Icelandic hot spring. Zbl Bakt Hyg, I Abt Orig C 2:166-178

Tu J, Prangishvilli D, Huber H, Wildgruber G, Zillig W, Stetter KO (1982) Taxonomic relations between archaebacteria including 6 novel genera examined by cross hybridization of DNAs and $16 \mathrm{~s}$ rRNA. J Mol Evol (in press)

Wildgruber G, Thomm M, König H, Ober K, Ricchiuto T, Stetter KO (1982) Methanoplanus limicola, a plate-shaped methanogen representing a novel family, the Methanoplanaceae. Arch Microbiol in press)

Zeikus JG, Arie Ben-Bassat, Hegger PW (1980) Microbiology of methanogenesis in thermal, volcanic environments. J Bacteriol $143: 432-440$

Zeikus JG, Wolfe RS (1972) Methanobacterium thermoautotrophicum sp. $\mathrm{n}$., an anaerobic, autotrophic, extreme thermophile. J Bacteriol 109:707-713

Zcikus JG, Wolfe RS (1973) Finestructure of Methanobacterium thermoautotrophicum. Effect of growth temperature on morphology and ultrastructure. J Bacteriol 113:461 - 476

Zillig W, Stetter KO, Wunderl S, Schulz W, Priess H, Scholz J (1980) The Sulfolobus-"Caldariella" group: Taxonomy on the basis of the structure of DNA-dependent RNA polymerase. Arch Microbiol $125: 259-269$

Zinder SH, Mah RA (1979) Isolation and characterization of a thermophilic strain of Methanosarcina unable to use $\mathrm{H}_{2}-\mathrm{CO}_{2}$ for methanogenesis. Appl Environ Microbiol 38:996-1008

Received March 26, 1982/Accepted April 24, 1982 